Research Article

\title{
Evaluation of Nestin and Reelin Genes Expression in the brain of Hypothyroid Neonatal Rats Treated with Emamectin Benzoate during Lactation Period
}

\author{
Aya Ahmed Mohamed ${ }^{1}$, Khairy Abdel Moneim², Ibrahim Yehia Abdel Kader ${ }^{1}$, Abdel Rahman Tawfik ${ }^{1}$ \\ ${ }^{1}$ Cairo University-Faculty of Science-Zoology Department, Egypt. \\ 2 Agricultural Research Center-Toxicology Department, Egypt. \\ *Corresponding author's E-mail: ahmed.gaber2222@yahoo.com
}

Received: 18-01-2021; Revised: 22-02-2021; Accepted: 28-02-2021; Published on: 20-03-2021.

\section{ABSTRACT}

The present proposal objective is to focus on the glycoprotein reelin and nestin. The two genes regulation was testified in case of hypothyroidism and/or the pesticide emamectin benzoate intoxication and the relationships between them and DNA damage in hand and apoptosis in another hand. Male and female albino rats (Rattus norvegicus) aged $12-14$ weeks, were used. Male rats were allowed to mate with females. The pregnant rats were then isolated from male rats and housed in separate cages. After delivery, mothers and pups were grouped as control group, carbimazole group (positive control for hypothyroidism), emamectin benzoate group, and mixed group of emamectin benzoate and carbimazole group. At the 10th and 21st days, six neonatal rats from each group were withdrawn. Plasma samples were prepared and used for thyroid hormones determination. The brains were removed and used for the biochemical parameters. After oral gavages with CBZ, EMB, and their combination, the concentrations of total T3 and T4 of neonatal rats were decreased. While reelin $m R N A$ gene expression was significantly decreased $(P<0.01)$ as compared to control after oral gavages with $\mathrm{CBZ}, \mathrm{EMB}$, and their combination, nestin was significantly up regulated. Caspase- 3 mRNA was significantly increased after oral gavages with $\mathrm{CBZ}, \mathrm{EMB}$, and their combination. Comet assay showed the elevated levels of comet tail DNA and tail moment and a decrease in head DNA. The pesticide emamectin benzoate considered as a teratogen due to its embryotoxic effects.

Keywords: Hypothyroidism, Emamectin benzoate, Carbimazole, Reelin, Nestin, Caspase-3, Comet assay.

QUICK RESPONSE CODE $\rightarrow$

DOI:

10.47583/ijpsrr.2021.v67i01.026

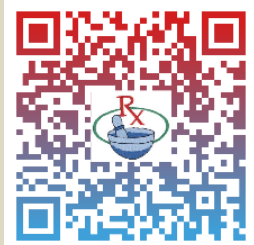

DOI link: $\underline{\text { http://dx.doi.org/10.47583/ijpsrr.2021.v67i01.026 }}$

\section{INTRODUCTION}

T hyroid gland is one of the major and essential vertebrate endocrine gland. Thyroid hormones are liberated into blood largely as the precursor thyroxin tetraiodothyronine (T4) as well as lower amounts of the active form of $\mathrm{T}^{1}$. During neurodevelopment, the brain is highly sensitive to thyroid hormone action ${ }^{2}{ }^{\prime} 3$. Hypothyroid rat brains have been shown to have a reduction in myelination, as a result reduction of the major myelin proteins and disruption of oligodendrocyte differentiation ${ }^{4}$.

Emamectin benzoate (EMB) is an essential macrocyclic lactones insecticide derived from the avermectin that is developed for the control of insect pests ${ }^{5}$. The avermectins are powerful insecticides that are thought to exhibit their effect on the $\gamma$-amino butyric acid-mediated neuromuscular synapse, with chloride channels appearing to be particularly sensitive ${ }^{6}$.

The reelin gene is localized to chromosome 7 in man $^{7}$. Reelin is a crucial positional signal for layer formation and differentiation of the brain. Reelin is a large-molecular- weight protein secreted during early embryonic development into the extracellular matrix by Cajal-Retzius cells, a temporary population of GABAergic neurons located in the uppermost layer of the developing cortex, marginal zone ${ }^{8}$. Reelin is involved in several aspects of brain development, such as cell positioning, dendrite growth, synaptic plasticity, memory, and may be implicated as a vulnerability element in psychoses $9,10$.

Nestin is a class VI intermediate filament protein and neuroepithelial stem cell marker ${ }^{11 .}$ During early stages of development, nestin is expressed in dividing cells in the central nervous system, peripheral nervous system, and in myogenic and other tissues. During differentiation in normal brain tissue, nestin expression is down regulated and replaced by expression of tissue-specific intermediate filament proteins; therefore, nesting is widely used as a neuronal stem cell marker. Nestin is also expressed in immature non-neuronal cells and progenitor cells in normal tissues 12.

Caspase-3 plays an essential purpose for many key events during apoptosis such as nuclear destruction and DNA damage ${ }^{13}$. Caspase-3 was reported to play a role as an amplifier of the apoptotic signals i.e. by the cleavage of Bcl$2^{14}$. Apoptosis or programmed cell death is necessary for organogenesis during development, proper function of the immune system, removal of genetically instable cells, and maintenance of tissue homeostasis in the adult ${ }^{15}$. Apoptosis results from activation of members of the caspase family of aspartate-specific proteases ${ }^{16,17}$. 


\section{Aim of the Work}

The present proposal objective is to focus on a stressrelated investigation of the glycoprotein reelin and nestin. The two genes regulation were testified in case of hypothyroidism and/or emamectin benzoate intoxication and the relationships between them and DNA damage in hand and apoptosis in another hand.

\section{MATERIALS AND METHODS}

\section{Pesticides and thyroid drug}

The pesticide $E M B$ was dissolved in corn oil in final volume of $1 \mathrm{ml} / \mathrm{kg}$ body weight before use. Carbimazole (CBZ) from Sigma was prepared daily by dissolving in water and animals were received $6 \mathrm{mg} / \mathrm{Kg}$ body weight.

\section{Animals}

The handling of the laboratory animals during the experimental work was performed according to the guidance for care and use of IACUC (Institutional Animal The handling of the laboratory animals during the experimental work was performed according to the guidance for care and use of IACUC (Institutional Animal Care and Use Committee) with approval number $\mathrm{CU} / \mathrm{I} / \mathrm{F} / 19 / 18$.

Male and female albino rats (Rattus norvegicus) aged 12 14 weeks, were obtained from the breeding colony of the Mammalian Toxicology Department - Central Agricultural Pesticides Lab, Giza, Egypt. Females (2-3) had been transferred into each male cage for mating. The pregnant rats were isolated from male rats and housed in separate cages.

\section{Experimental design}

After delivery (Postnatal zero day), mothers and pups were grouped as the following:

\section{Control group}

Mothers were received water daily through the lactation period.

\section{Emamectin benzoate group}

Mothers were received $0.479 \mathrm{mg} / \mathrm{kg}$ (equivalent to $1 / 200$ $\left.L_{50}\right)$ of EMB daily from day 1 to day 21 of lactation. The acute oral median lethal dose $\left(L_{50}\right)$ of $E M B$ for female rats was undertaken according to the guideline of EPA (Environmental Protection Agency) for acute oral toxicity. $\mathrm{LD}_{50}$ values were derived by the moving average method using special tables ${ }^{\mathbf{1 8}}$.

\section{Carbimazole group (positive control for hypothyroidism)}

Mothers were received $6 \mathrm{mg} / \mathrm{kg}$ of carbimazole daily from day 1 to day 21 of lactation.

\section{Emamectin benzoate and carbimazole group}

Mothers were received $0.479 \mathrm{mg} / \mathrm{Kg}$ of $\mathrm{EMB}$ and $6 \mathrm{mg} / \mathrm{Kg}$ of carbimazole daily from day 1 to day 21 of lactation.
At the $10^{\text {th }}$ and $21^{\text {st }}$ days, six neonatal rats from each group were withdrawn. They were slightly anaesthetized with ether and the blood samples were collected in heparinized tubes from retro-orbital plexus ${ }^{19}$. The tubes were immediately centrifuged using Sigma Laboratory Centrifuge (3K30, Germany) at 3600 r.p.m for $15 \mathrm{~min}$. Plasma samples were separated and kept at $-80 \mathrm{C}^{\circ}$ until used for thyroid hormones determination. The brains were removed and quickly frozen at $-80{ }^{\circ} \mathrm{C}$ and saved for the biochemical parameters.

\section{Methods}

\section{Thyroid hormones assay}

Immunoassays for the in vitro quantitative determination of total triiodothyronine (T3) and thyroxin (T4) in blood were obtained from Atlas Medical, UK.

\section{Determination of gene expressions of reelin, nestin, and caspase-3}

Reelin, nestin, and caspase-3 mRNA gene expressions were determined by RT-PCR (Real-Time Polymerase Chain Reaction). All PCR experiments were performed in the Eppendorf, Realplex instrument, Germany for the signal detection and analysis. Gene-specific primers were designed based on the gene sequences of Rattus norvegicus present on the NCBI homepage (http://www.ncbi.nlm.nih.gov). Expression was normalized to ß-actin gene, which was used as an internal housekeeping control. Highly purified salt-free primers were obtained from Metabion, Germany and the sequences of these primers obtainable in table (1).

Table 1: Oligonucleotide primers used in SYBR green real time PCR

\begin{tabular}{|l|l|}
\hline Genes & Primer sequence (5'-3') \\
\hline B-actin $^{20}$ & $\begin{array}{l}\text { F-TCCTCCTGAGCGCAAGTACTCT } \\
\text { R-GCTCAGTAACAGTCCGCCTAGAA }\end{array}$ \\
\hline Reelin ${ }^{21}$ & F-AAACTACAGCGGGTGGAACC \\
& R-ATTTGAGGCATGACGGACCTATAT \\
\hline Nestin 22 & F-CTGAGGCCTCTCTTCTTCCA \\
& R-ACTCCTGTACCGGGTCTCCT \\
\hline Caspase3 $^{23}$ & F-AGTTGGACCACCTTGTGAG \\
& R-AGTCTGCAGCTCCTCCACAT
\end{tabular}

\section{Calculation of mRNA expression levels}

To estimate the variation of gene expression on the RNA of the different samples, the threshold cycle (Ct) of each sample was compared with that of the control group according to the " $\Delta \Delta \mathrm{Ct}$ " method stated by ${ }^{\mathbf{2 4}}$.

\section{Single-cell gel electrophoresis (Comet assay)}

The comet assay used in the present study applied under alkaline conditions using ordinary microscope slides as previously described by ${ }^{25}$. For visualization of DNA damage, observations were made of EtBr-stained DNA using a 40x objective on a fluorescent microscope. The degree of DNA damage was performed on coded slides by 
one reader to avoid variability by komet 5 image analysis software (Liverpool, UK) linked to a CCD camera.

\section{Statistical analysis}

A computer program, the statistical package for social science (SPSS 17.0), was used for statistical analysis. One way analysis of Variance (ANOVA) followed by post hoc least significant difference test (LSD) for multiple comparisons were used. The data were expressed as means \pm standard error (SE).Differences between the groups were considered as statistically significant when $p$ $<0.05$, highly significant when $p<0.01$ and very highly significant when $\mathrm{p}<0.001$.

\section{RESULTS}

\section{Thyroid hormones assay:}

\section{Total Tri-iodothyronine (T3)}

The concentrations of $T_{3}$ of neonatal rats were significantly decreased as compared to the control after oral gavages with CBZ $(P<0.05), E M B(P<0.05)$, and their combination $(P<0.01)$ by percentage differences of 22.91, 14.29, and 34.78 , respectively (Table 2 ). While rats received mixture of $C B Z$ and $E M B$ showed non-significant change in the concentration of $\mathrm{T} 3$ as compared rats received $\mathrm{CBZ}$, significant reduction $(\mathrm{P}<0.05)$ as compared to the rats received $E M B$ by percentage difference of 23.90, was observed (Table 2).

\section{Total Tetra-iodothyronine (T4)}

While the oral gavages of rats with EMB showed nonsignificant decrease in the concentrations of plasma T4 as compared to control, rats received CBZ or mixture showed significant decrease $(P<0.05)$ in the concentrations of plasma T4 as compared to the control by percentage differences of 57.03 and 49.63, respectively (Table 2). Statistical analysis also revealed that there were nonsignificant differences in the concentrations of plasma T4 as compared between all other groups studied (Table 2).

Table 2: Plasma total concentrations (means \pm S.E.) of $T_{3}$ and $\mathrm{T}_{4}(\mu \mathrm{lU} / \mathrm{ml})$ of neonatal rats treated during lactation period

\begin{tabular}{|c|c|c|}
\hline & Total T3 & Total T4 \\
\hline Control & $94.30 \pm 3.07$ & $2.70 \pm 0.64$ \\
\hline CBZ & $72.70 \pm 1.01^{\mathrm{a}}$ & $1.16 \pm 0.19^{\mathrm{a}}$ \\
\hline EMB & $80.82 \pm 5.08^{\mathrm{a}}$ & $2.14 \pm 0.12$ \\
\hline Mixture & $61.5 \pm 6.01^{\mathrm{a}, \mathrm{c}}$ & $1.36 \pm 029^{\mathrm{a}}$ \\
\hline
\end{tabular}

(a) Significant decrease as compared to control.

(c) Significant decrease as compared to EMB.

\section{Reelin gene expressions}

\section{$10^{\text {th }}$ day of lactation period}

The reelin mRNA gene expression was significantly decreased $(P<0.01)$ as compared to control after oral gavages with $\mathrm{CBZ}, \mathrm{EMB}$, and their combination 71.6, 35.3, and 85.3 fold changes, respectively (Table 3 ). While rats received the mixture of $C B Z$ and $E M B$ showed a significant decrease $(P<0.01)$ in reelin mRNA gene expression as compared with the rats received only EMB by percentage difference of 72.7, a non-significant change was observed as compared to the expression in CBZ group (Table 3).

\section{$21^{\text {st }}$ day of lactation period}

Statistical analysis revealed that the expressions of reelin mRNA gene were significantly down regulated as compared to control group after oral gavages with $C B Z$ $(P<0.01), E M B(P<0.05)$, and the mixture $(P<0.01)$ by 54.9 , 20.59, and 60.78 fold changes, respectively (Table 3).While rats received the mixture scored non-significant change in the expressions of reelin mRNA gene as compared to rats received $C B Z$, a significant decrease $(P<0.01)$ by percentage difference of 50.62 was observed as compared to rats received EMB (Table 3 ).

On comparing the data at $21^{\text {st }}$ and $10^{\text {th }}$ day of lactation, only a significant increase $(P<0.05)$ was observed with a percentage difference of 166.66 in the expressions of reelin $\mathrm{mRNA}$ gene between rats received mixture of $C B Z$ and EMB (Table 3).

\section{Nestin mRNA gene expression}

\section{$10^{\text {th }}$ day of lactation period}

Statistical analysis revealed that mRNA gene expression of nestin was significantly up regulated $(P<0.01)$ as compared to control after oral gavages with $\mathrm{CBZ}, \mathrm{EMB}$, and their combination by 74.4-, 31.0-, and 103.5-fold changes, respectively (Table 3 ). Rats received mixture of $C B Z$ and $E M B$ showed significant increases $(P<0.01)$ in the nestin mRNA gene expression as compared to rats received $C B Z$ or EMB by percentage differences of 34.52 and 177.01, respectively (Table 3 ).

\section{$21^{\text {st }}$ day of lactation period}

Statistical analysis revealed that the mRNA gene expression of nestin was significantly increased after oral gavages with CBZ $(P<0.01)$, EMB $(P<0.05)$, and their combination $(P<0.01)$ as compared with control group by 485.29, 191.18, and 752.94 fold changes, respectively (Table 3 ). Rats received mixture of CBZ and EMB showed significant increases $(P<0.01)$ in the nestin mRNA gene expression as compared to rats received CBZ or EMB by percentage differences of 45.73 and 192.93 , respectively (Table 3).

On comparing the data at $21^{\text {st }}$ and $10^{\text {th }}$ day of lactation, significant decreases in the nestin mRNA gene expression were observed between rats received EMB $(P<0.01)$ with a percentage difference of 29.62 and rats received mixture of $C B Z$ and $E M B(P<0.05)$ with a percentage difference of 25.58 (Table 3). 


\section{Caspase-3 gene expressions}

\section{$10^{\text {th }}$ day of lactation period}

It was observed that the gene expressions of caspase-3 mRNA were significantly increased after oral gavages with CBZ $(P<0.01)$, EMB $(P<0.05)$, and their combination $(P<0.01)$ by $42.6,15.8$, and 66.9 fold changes, respectively as compared to the control (Table 3 ). Rats received mixture of $C B Z$ and $E M B$ showed significant increases $(P<0.01)$ in the gene expressions of caspase- 3 mRNA as compared to rats received $C B Z$ or $E M B$ by percentage differences of 46.33 and 197.70, respectively (Table 3).

\section{$21^{\text {st }}$ day of lactation period}

The mRNA gene expressions of nestin were significantly increased $(P<0.01)$ after oral gavages with $C B Z, E M B$, and their combination as compared with control group by $192.16,82.35$, and 366.68 fold changes, respectively (Table 3). Rats received mixture of CBZ and EMB showed significant increases $(P<0.01)$ in the gene expressions of caspase- 3 mRNA as compared to rats received CBZ or EMB by percentage differences of 59.40 and 155.38, respectively (Table 3 ).

The gene expressions of caspase-3 mRNA at 21st day of lactation showed significant decreases $(P<0.01)$ as compared to those at $10^{\text {th }}$ day of lactation in case of rats received $C B Z, E M B$, and mixture with a percentage changes of $43.88,28.74$, and 38.86 , respectively (Table 3 ).

\section{Comet assay during lactation period}

\section{Head DNA}

\section{$10^{\text {th }}$ day of lactation period}

There were significant decreases $(P<0.05)$ in head DNA after oral gavages with $\mathrm{CBZ}, \mathrm{EMB}$, and their combination $(P<0.01)$ by percentage changes of $9.50,14.02$, and 38.17 , respectively as compared to the control (Table 4$)$. Rats received mixture of $C B Z$ and $E M B$ showed significant decreases $(P<0.01)$ in head DNA as compared to CBZ or EMB by percentage changes of 31.68 and 25.04, respectively (Table 4).

\section{$21^{\text {st }}$ day of lactation period}

While rats received oral gavages with CBZ showed nonsignificant decrease in head DNA as compared to the control, there were significant decreases in head DNA after oral gavages with $E M B(P<0.05)$ and their combination $(P<0.01)$ as compared to the control by percentage changes of 8.21 and 17.21 , respectively (Table 4 ).
Rats received mixture of $C B Z$ and $E M B$ showed significant decreases $(P<0.01)$ in head DNA as compared to CBZ or $\mathrm{EMB}$ by percentage changes of 13.52 and 9.81, respectively (Table 4).

The data of head DNA at 21st day of lactation showed nonsignificant changes as compared to those at 10th day of lactation in case of rats received CBZ, EMB, and mixture (Table 4).

\section{Tail DNA}

\section{$10^{\text {th }}$ day of lactation period}

Rats received $C B Z, E M B$, and mixture showed significant increases $(P<0.01)$ in tail DNA as compared to the control by percentage changes of 20.1, 28.8, and 74.9, respectively (Table 5). Rats received mixture of CBZ and EMB showed significant increases in tail DNA $(P<0.01)$ as compared to CBZ by percentage change of 64.0 and EMB by percentage change of 54.4 (Table 4).

\section{$21^{\text {st }}$ day of lactation period}

Rats received $C B Z$, EMB showed non-significant differences in tail DNA as compared to the control but mixture showed significant increase $(P<0.01)$ by percentage changes of 24.6 (Table 4). Rats received mixture of $C B Z$ and $E M B$ showed significant decreases in tail DNA $(P<0.01)$ as compared to both $C B Z$ by percentage change of 64.0 and EMB by percentage change of 54.4 (Table 4).

Non-significant changes were observed as compared the data of tail DNA between $21^{\text {st }}$ day of lactation period and $10^{\text {th }}$ day of lactation period (Table 4).

\section{Tail moment}

\section{$10^{\text {th }}$ day of lactation period}

Significant increases in tail moment as compared to the control were observed when rats received CBZ $(P<0.05)$, EMB $(P<0.05)$, and mixture $(P<0.01)$ by percentage changes of 73.3, 191.1 and 503.3, respectively (Table 4). Rats received mixture of $C B Z$ and $E M B$ showed significant increases in tail moment $(P<0.01)$ as compared to $C B Z$ by percentage change of 83.1 and $\mathrm{EMB}$ by percentage change of 60.1 (Table 4).

\section{$21^{\text {st }}$ day of lactation period}

Rats received $C B Z, E M B$, and mixture showed nonsignificant changes in tail moment as compared to the control (Table 4). Rats received mixture of CBZ and EMB showed non-significant increases in tail DNA as compared to CBZ and EMB (Table 4). 
Table 3: Reelin, Caspase-3, and Nestin mRNA gene expressions (means $\pm S . E$.) of neonatal rats during lactation period

\begin{tabular}{|c|c|c|c|c|c|c|}
\hline & \multicolumn{2}{|c|}{$\begin{array}{l}\text { Reelin mRNA gene } \\
\text { expressions }\end{array}$} & \multicolumn{2}{|c|}{$\begin{array}{c}\text { Nestin mRNA gene } \\
\text { expressions }\end{array}$} & \multicolumn{2}{|c|}{$\begin{array}{c}\text { Caspase- } 3 \text { mRNA gene } \\
\text { expressions }\end{array}$} \\
\hline & $\begin{array}{l}10^{\text {th }} \text { day of } \\
\text { lactation }\end{array}$ & $\begin{array}{c}21^{\text {st }} \text { day of } \\
\text { lactation }\end{array}$ & $\begin{array}{c}10^{\text {th }} \text { day of } \\
\text { lactation }\end{array}$ & $\begin{array}{c}21^{\text {st }} \text { day of } \\
\text { lactation }\end{array}$ & $\begin{array}{c}10^{\text {th }} \text { day of } \\
\text { lactation }\end{array}$ & $\begin{array}{c}21^{\text {st }} \text { day of } \\
\text { lactation }\end{array}$ \\
\hline $\begin{array}{l}\text { Control } \\
\text { CBZ } \\
\text { EMB } \\
\text { Mixture }\end{array}$ & $\begin{array}{c}1.02 \pm 0.01 \\
0.9 \pm 0.05^{a} \\
0.66 \pm 0.07^{a} \\
0.15 \pm 0.01 \\
a, c\end{array}$ & $\begin{array}{c}1.02 \pm 0.02 \\
0.46 \pm 0.033^{a} \\
0.81 \pm 0.03^{a} \\
0.40 \pm 0.08 \\
a, c, @\end{array}$ & $\begin{array}{c}1.03 \pm 0.08 \\
8.69 \pm 0.40 \mathrm{a}, \mathrm{b} \\
4.22 \pm 0.26^{\mathrm{a}} \\
11.69 \pm 0.82 \\
\mathrm{a}, \mathrm{b}, \mathrm{c}\end{array}$ & $\begin{array}{c}1.02 \pm 0.05 \\
5.97 \pm 0.45^{\mathrm{a}} \\
2.97 \pm 0.19 \mathrm{a}^{\mathrm{a}, * *} \\
8.70 \pm 0.49 \\
\mathrm{a}, \mathrm{b}, \mathrm{c},{ }^{*}\end{array}$ & $\begin{array}{c}1.01 \pm 0.01 \\
5.31 \pm 0.29^{a} \\
2.61 \pm 0.07^{a} \\
7.77 \pm 0.52 \\
a, b, c\end{array}$ & $\begin{array}{c}1.02 \pm 0.03 \\
2.98 \pm 0.31^{\mathrm{a},++} \\
1.86 \pm 0.17^{\mathrm{a},++} \\
4.75 \pm 0.20 \\
\mathrm{a}, \mathrm{b}, \mathrm{c},++\end{array}$ \\
\hline
\end{tabular}

(a) Significant change as compared to the control.

(b) Significant change as compared to CBZ group.

(c) Significant change as compared to EMB group.

@ Significant change as compared to the mixture group at $10^{\text {th }}$ day of lactation.

* Significant change as compared to the mixture group at $10^{\text {th }}$ day of lactation.

** Highly significant change as compared to the EMB group at $10^{\text {th }}$ day of lactation.

++ Highly significant change as compared to the data at $10^{\text {th }}$ day of lactation.

Table 4: Comet parameters (means \pm S.E.) of neonatal rats during lactation period rats during lactation period

\begin{tabular}{|c|c|c|c|c|c|c|}
\hline & \multicolumn{2}{|c|}{ Head DNA } & \multicolumn{2}{c|}{ Tail DNA } & \multicolumn{2}{c|}{ Tail Moment } \\
\hline & $\begin{array}{c}\mathbf{1 0}^{\text {th }} \text { day of } \\
\text { lactation }\end{array}$ & $\begin{array}{c}\mathbf{2 1}^{\text {st }} \text { day of } \\
\text { lactation }\end{array}$ & $\begin{array}{c}\mathbf{1 0}^{\text {th }} \text { day of } \\
\text { lactation }\end{array}$ & $\begin{array}{c}\mathbf{2 1}^{\text {st }} \text { day of } \\
\text { lactation }\end{array}$ & $\begin{array}{c}\mathbf{1 0}^{\text {th }} \text { day of } \\
\text { lactation }\end{array}$ & $\begin{array}{c}\mathbf{2 1}^{\text {st }} \text { day of } \\
\text { lactation }\end{array}$ \\
\hline Control & $95.58 \pm 2.59$ & $94.18 \pm 1.12$ & $4.42 \pm 2.59$ & $5.88 \pm 1.08$ & $0.09 \pm 0.01$ & $0.48 \pm 0.03$ \\
\hline CBZ & $86.50 \pm 1.27^{\mathrm{a}}$ & $90.16 \pm 1.54$ & $13.51 \pm 1.27^{\mathrm{a}}$ & $9.84 \pm 1.55$ & $0.75 \pm 2.36^{\mathrm{a}}$ & $0.67 \pm 0.22$ \\
\hline EMB & $82.18 \pm 1.98^{\mathrm{a}}$ & $86.45 \pm 1.04^{\mathrm{a}}$ & $17.15 \pm 1.79^{\mathrm{a}}$ & $13.55 \pm 1.4$ & $1.84 \pm 0.17^{\mathrm{a}}$ & $0.64 \pm 0.20$ \\
\hline Mixture & $59.10 \pm 3.50^{\mathrm{a}, \mathrm{b}, \mathrm{c}}$ & $77.97 \pm 3.59^{\mathrm{a}, \mathrm{b}, \mathrm{c}}$ & $37.56 \pm 1.49^{\mathrm{a}, \mathrm{b}, \mathrm{c}}$ & $20.36 \pm 4.78^{\mathrm{a}, \mathrm{b}, \mathrm{c}}$ & $4.62 \pm 0.40^{\mathrm{a}, \mathrm{b}, \mathrm{c}}$ & $2.94 \pm 2.17$ \\
\hline
\end{tabular}

(a) Significant decrease as compared to control

(b) Significant decrease as compared CBZ.

(c) Significant decrease as compared to EMB.

Non-significant changes were observed as compared the data of tail moment between $21^{\text {st }}$ day of lactation period and $10^{\text {th }}$ day of lactation period (Table 4).

\section{DISCUSSION}

Hypothyroidism is a disorder of the endocrine system in which the thyroid gland does not produce enough thyroid hormone. Some of the most obvious and prevalent symptoms of thyroid disease are those that result from the consequences of TH on the CNS ${ }^{26}$.

The present proposal aimed to testify the two genes, reelin and nestin, regulation in case of hypothyroidism and/or emamectin benzoate intoxication and the relationships between them and DNA damage in hand and apoptosis in another hand.

The results of the present study indicated that carbimazole produced hypothyroidism in neonatal rats during lactation which expressed as significant decrease in T3 and T4. Carbimazole is an anti-thyroid medication which is generally used to treat hyperthyroidism ${ }^{27}$. Carbimazole is a prodrug of the active structure methimazole which keeps the thyroid peroxidase enzyme from coupling and iodinating the tyrosine deposits on thyroglobulin, consequently decreasing the generation of T3 and T4 ${ }^{28}$.
The contents of breast milk are involved in myelin promotion and development ${ }^{29}$ and an increase in white matter volume in infant's breastfed ${ }^{30,31}$. Studies on the transfer of cabimazole into milk have shown that a higher proportion of an orally administered dose of the drug to the mother appears in the milk. The mean milk to serum ratio of cabimazole concentration is 1.0 with a mean excretion in breast milk over an 8-h period equal to $0.1-$ $0.17 \%$ of an orally administered dose ${ }^{32,33}$. Due to the higher potency of cabimazole, this drug could theoretically affect the infant's thyroid.

Thyroid toxicants as environmental factors are commonly change circulating levels of thyroid hormone ${ }^{34}$. In the present work, the oral gavages with the insecticide EMB decreases significantly the level of $\mathrm{T} 3$, but it scored a nonsignificant decrease in the level of $\mathrm{T} 4$ as compared to control. The data also indicated that the hypothyroid rats are subject to more reduction in the levels of $\mathrm{T} 3$ and $\mathrm{T} 4$ when exposed to the insecticide. EMB in combination with CBZ induced more reduction in the levels of T3 and T4 as 
compared to their levels in hypothyroid rats received only CBZ.

The significant decrease in T3 and not T4 may be due to that $\mathrm{T} 3$ is produced directly in small amounts by the thyroid gland ${ }^{35}$ while the majority of the circulating T3 hormone derives from the peripheral conversion of T4, the major glandular product, to T3 in target tissues by an outer ring $\left(5^{\prime}\right)$ iodothyronine-deiodinase.

The developing brain is dependent on a supply of T4, which is locally converted to $\mathrm{T}^{36}$. This emphasizes the need for maternal T4 levels to be maintained to ensure normal fetal brain development. This also explains why even minimally reduced maternal T4 levels in early pregnancy results in adverse outcomes to the offspring ${ }^{37,38}$.

Toxicological data collection and analysis for many pesticides to support grouping of pesticide active substances for cumulative risk assessment of effects on the nervous system, liver, adrenal, eye, reproduction and development and thyroid system were done as external scientific report in 2016. In the mammalian toxicology section, a data gap was identified for assessment of the effect of emamectin benzoate on thyroid. United States Environmental Protection Agency/ Office of Pesticide Programs Organizational Chart (U.S. EPA/OPP) addresses endocrine function but does not identify any data on emamectin benzoate that suggests that this compound or its metabolites are endocrine disruptors. Furthermore, there is no information in the open literature or available toxicity data to suggest that EMB affects endocrine function ${ }^{39}$.

In rodents, several hundred genes regulated by $T_{3}$ at the transcriptional level are known to be involved in basic neuro-developmental events $\mathbf{4 0 , 4 1 , 4 2 , 4 3}$. Although postnatal cerebral cortex maturation is comparatively longer in humans than in rats ${ }^{44}$, similarities have been established since most of these T3-regulated genes are involved in evolutionary preserved pathways affecting the establishment of neural connections 40, 45, 41. Postnatal hypothyroid rats have been used to mimic human congenital hypothyroidism ${ }^{46}$ and genes involved in neuron-glia adhesion, affecting myelination, have been found to be under-expressed in these rats ${ }^{47,48}$.

In the present work, reelin mRNA gene expression was significantly decreased as compared to the control at $10^{\text {th }}$ and $21^{\text {st }}$ day of lactation after oral gavages with CBZ and EMB. The hypothyroid rats that orally administrated with CBZ showed more significant reduction after oral gavages with the insecticide EMB. On comparing the decrease at $21^{\text {st }}$ with $10^{\text {th }}$ day of lactation, a significant value was observed in the expressions of reelin mRNA gene only between rats received mixture of $C B Z$ and $E M B$.

In situ hybridization, and immunohistochemistry studies, hypothyroid rats expressed decreased levels of reelin RNA and protein during the perinatal period ${ }^{49}$. They suggested that the effects of thyroid hormone on neuronal migration may be in part mediated through the control of reelin expression during brain ontogenesis. They added that the T3 treatment of hypothyroid organotypic brain slices in vitro restores the normal reelin expression levels which strongly suggest a direct effect of this hormone. They reported that that $\mathrm{TH}$ deficiency affected on reelin expression, though advanced stages of development.

The real time RT-PCR revealed that T3 administration lead to a significant increase in reelin in the hippocampus ${ }^{50}$. The down regulation in reelin $\mathrm{mRNA}$ gene expression may be attributed to the deficiency in the thyroid hormones after emamectin benzoate and/or carbimazole treatment ${ }^{51}$. T3 was shown to regulate the gene of reelin which is responsible for the migration of neuronal cells during neurodevelopment.

The roles of DNA methylaion and histone acetylation in the effects of perinatal hypothyroidism on regulation of reelin and brain-derived neurotrophic factor (BDNF) gene expression in rat hippocampus were investigated ${ }^{52}$. They indicated that the activities of DNA methyltransferase (DNMT), methylated reelin and BDNF genes were upregulated, whereas, the activities of histone acetylases (HAT), the levels of global acetylated histone $3(\mathrm{H} 3)$, global acetylated histone $4(\mathrm{H} 4)$, acetylated $\mathrm{H} 3$, and acetylated $\mathrm{H} 4$ at reelin promoter and at BDNF gene promoter for exon II were down-regulated in the hippocampus at the developmental stage of the hypothyroid animals. These results suggest that the epigenetic modification of chromatin might underlie the mechanisms of hypothyroidism-induced down-regulation of reelin and BDNF gene expression in developmental rat hippocampus.

It has been reported that the interruption of actions of thyroid hormones by anti-thyroid drugs such as methimazole or Neonatal 6-n-propyl-2-thiouracil (PTU) during the fetal and neonatal period of vertebrates results in impairment of hepatic gene expression in adulthood ${ }^{53}$, 54

Cytoskeletal system which consists of microtubules (tubulin), microfilaments (actin), and intermediate filaments, specific for neurons (neurofilaments), glia (glial fibrillary acidic protein), or maturing cells (vimentin, nestin) can play important roles in neural cell shape and neuronal migration and outgrowth ${ }^{55}$. With respect to the mRNA gene expression of nestin and in contrast to the reelin mRNA gene expression, significant increases at $10^{\text {th }}$ and $21^{\text {st }}$ day of lactation after oral gavages with $C B Z$ and EMB as compared with control, were observed. The hypothyroid rats that orally administrated with CBZ showed more significant increase after oral gavages with the insecticide EMB. On comparing the increase at $21^{\text {st }}$ and $10^{\text {th }}$ day of lactation, significant values in the nestin mRNA gene expression were observed between rats received $E M B$ and rats received mixture of $C B Z$ and $E M B$.

Nestin is expressed by many types of cells during development, although its expression is usually transient and does not persist into adulthood. Upon differentiation, nestin becomes down regulated and is replaced by cell 
type-specific intermediate filaments, e.g. neurofilaments and glial fibrillary acidic protein (GFAP). Nestin expression is re-induced in the adult during pathological situations, such as the formation of the glial scar after central nervous system injury and during regeneration of injured muscle tissue ${ }^{56}$.

In maternal hypothyroidism, there was reduction in the expression of glial fibrillary acidic protein, an intermediate filament (IF) protein that is expressed by numerous cell types of the central nervous system in fetal late gestation. This alters the development of cellular cytoskeleton, synthesis of microtubule protein, axonal transport, neuronal outgrowth and neuronal behavior ${ }^{57}$.

In abnormal conditions, nestin is re-expressed during repair processes, as well as in different neoplasms and proliferating endothelial cells ${ }^{58}$. During normal development, astroglial cells expressed nestin, vimentin, and glial fibrillary acidic protein ${ }^{59}$. Differences between normal and hypothyroid rats were observed starting from postnatal day 4, with lack of differentiated astrocytes in the internal granular layer. The transient decrease of astrocyte markers immunoreactivity in the anterior lobe did not take place in hypothyroid rats that might keep the nestin at its level.

There relation between nestin expression and cell proliferation is also observed in neoplastic transformation. For example, sufficient nestin expression was determined in various cancers such as neuroblastoma, glioma, and melanoma and higher levels of expression appear to correlate with greater malignancy ${ }^{60,61}$. A marked shift in the nestin cellular expression patterns towards activated microglia/macrophages and astrocytes was observed following innate immune challenge by lipopolysaccharide (LPS) injection and in response to ischemic injury ${ }^{62}$. Based on these findings, they proposed that nestin may have a role as a context-dependent biomarker.

In myelodysplastic syndromes bone marrow there was an increase in a distinct subset of nestin-expressing cells ${ }^{63}$. The origin of these cells was elusive, but the Shwann cells normally present along with the arterial/arteriolar structures could be a candidate, because in the normal bone marrow, a portion of glial fibrillary acidic proteinexpressing cells along with the vascular structures expressed nestin.

Apoptosis is an essential cellular phenomenon during development and is critical for the cytotoxicity stimulated by drugs characterized by the rupture of chromatin DNA into inter-nucleosomal fragments ${ }^{64,}{ }^{65}$. Caspases are critical mediators of programmed cell death ${ }^{66}$.

In the present work, it was observed that the gene expressions of caspase-3 mRNA were significantly increased after oral gavages with $\mathrm{CBZ}$ and $\mathrm{EMB}$ at $10^{\text {th }}$ and $21^{\text {st }}$ day of lactation as compared to the control. The insecticide EMB was shown to induce more significant increase in the gene expressions of caspase-3 mRNA in case of hypothyroid rats (that orally administrated with
CBZ). The gene expressions of caspase- 3 mRNA at $21^{\text {st }}$ day of lactation showed significant change as compared to those at $10^{\text {th }}$ day of lactation in case of rats received $C B Z$, $E M B$, and mixture.

Thyroid hormones maintain mitochondrial architecture and inhibit the release of apoptogenic molecules to prevent excess apoptosis during cerebellar development ${ }^{67}$. The mechanism for the apoptosis of hippocampus neuron was induced by hypothyroidism in prenatal rats ${ }^{68}$. Electron microscopy showed that altered morphology of mitochondria significantly increased under hypothyroid conditions. The expression of Bax in the cytosol of hypothyroid pups was higher than that of control pups. The intrinsic death pathway in mitochondria may be one of the mechanisms with which hypothyroid induces apoptosis of hippocampus neuron in developing rats.

The molecular events that lead to enhanced cell death in rat cerebellum under hypothyroidism were recognized ${ }^{69}$. Results showed that prenatal hypothyroidism besides repressing the expression of brain-derived neurotrophic factor also impairs the maturation of nerve growth factor which results in decreased activation of extracellular signal-regulated kinases, CAMP response element-binding protein, nuclear factor kappa-light-chain-enhancer of activated B cells, and Protein kinase B. Furthermore hypothyroidism caused an enhanced expression and proteolysis of p75 neurotrophin receptor (nerve growth factor receptor).

The principal secretary product of the thyroid gland, Lthyroxin (T4), is anti-apoptotic at physiological concentrations in a number of cancer cell lines ${ }^{70}$. The hormone decreases cellular abundance and activation of proteolytic caspases and of $B A X$ and causes increased expression of X-linked inhibitor of apoptosis (XIAP). By a variety of mechanisms, thyroid hormone (T4) is an endogenous anti-apoptotic factor that may oppose chemotherapy-induced apoptosis in $\alpha v \beta 3$-expressing cancer cells. T4 can interfere with the Ser-15 phosphorylation of p53 and with TNF $\alpha /$ Fas-induced apoptosis and blocks their apoptotic action. It is possible to decrease this anti-apoptotic activity pharmacologically by reducing circulating levels of $\mathrm{T} 4$ or by blocking effects of T4 that are initiated at $\alpha v \beta 3$ receptor.

The basic features of the morphological sings of apoptosis are DNA remnants and condensed chromosomal DNA ${ }^{71}$. The comet assay, a technique capable of detecting DNA damage in individual cells, is a valuable approach for human biomonitoring studies ${ }^{72}$, 73. DNA strand breaks allow DNA to extend from lysed and salt-extracted nuclei, or nucleoids, to form a comet-like tail on alkaline electrophoresis.

Another evidence supported these results is the elevated levels of comet tail DNA and tail moment in the present study. Rats received $C B Z$ or $E M B$ showed significant increases in tail DNA, tail moment and significant decrease in head DNA. While more reduction was observed in head 
DNA when hypothyroid rats administrated with CBZ orally gavages with the insecticide $E M B$, more elevation in tail DNA, and tail moment, were observed. Non-significant changes were observed in head DNA, tail DNA, and tail moment as compared the data between $21^{\text {st }}$ and $10^{\text {th }}$ day of lactation period.

The exposure to insecticides such as methomyl and avermectin can induce DNA damage that is involved in the genotoxic process in cells ${ }^{74,75}$.

\section{In summary,}

- The pesticide emamectin benzoate can cause a case of hypothyroidism to the neonate rats during lactation.

- Thyroid hormones regulate the expression of reelin but not nestin.

- Hypothyroidism can cause down-regulation of mRNA gene expression of reelin which is responsible for mylination of nerves in brain.

- The increase in the mRNA gene expression of nestin could be pathologically induced due to the hypothyroidism and toxicity of emamectin benzoate.

- Hypothyroidism can alter the morphology of the mitochondria significantly to release death factors into cytosol that activate caspase-3 and evoked DNA damage causing the apoptosis.

From the forgoing discussion and the previous work ${ }^{75}$ which indicated that the teratogenicity of EMB may be mediated by its ability to elevate apoptosis and DNA damage in brain and liver during organogenesis of the fetuses in albino rats, pregnant and lactated females especially with a case of hypothyroidism should avoid the exposure to $E M B$ during these periods.

\section{REFERENCES}

1. Williams GR. Neurodevelopmental and Neurophysiological Actions of Thyroid Hormone. Journal of Neuroendocrinology. 2008; 20(6): 784-94.

2. Grimaldi A, Buisine N, Miller T, Shi YB, Sachs LM. Mechanisms of thyroid hormone receptor action during development: lessons from amphibian studies. Biochimica et Biophysica Acta (BBA)-General Subjects. 2013 Jul 1; 1830(7): 3882-92.

3. Préau L, Fini JB, Morvan-Dubois G, Demeneix B. Thyroid hormone signaling during early neurogenesis and its significance as a vulnerable window for endocrine disruption. Biochimica et Biophysica Acta (BBA)-Gene Regulatory Mechanisms. 2015 Feb 1; 1849(2): 112-21.

4. Billon N, Jolicoeur C, Tokumoto $Y$, Vennström B, Raff M. Normal timing of oligodendrocyte development depends on thyroid hormone receptor alpha 1 (TR $\alpha 1$ ). The EMBO journal. 2002 Dec 1; 21(23): 6452-60.

5. El-Sheikh ES. Comparative toxicity and sublethal effects of emamectin benzoate, lufenuron and spinosad on Spodoptera littoralis Boisd.(Lepidoptera: Noctuidae). Crop Protection. 2015 Jan 1; 67: 228-34.
6. Turner MJ, Schaeffer JM. Mode of action of ivermectin. Inlvermectin and abamectin 1989 (pp. 73-88). Springer, New York, NY.

7. DeSilva U, D'Arcangelo G, Braden VV, Chen J, Miao GG, Curran T, Green ED. The human reelin gene: isolation, sequencing, and mapping on chromosome 7. Genome research. 1997 Feb 1; 7(2): 157-64.

8. Costa E, Davis J, Pesold C, Tueting P, Guidotti A. The heterozygote reeler mouse as a model for the development of a new generation of antipsychotics. Current opinion in pharmacology. 2002 Feb 1; 2(1): 56-62.

9. Beffert U, Weeber EJ, Durudas A, Qiu S, Masiulis I, Sweatt JD, Li WP, Adelmann G, Frotscher M, Hammer RE, Herz J. Modulation of synaptic plasticity and memory by Reelin involves differential splicing of the lipoprotein receptor Apoer2. Neuron. 2005 Aug 18; 47(4): 567-79.

10. Fatemi SH. Reelin glycoprotein: structure, biology and roles in health and disease. Molecular psychiatry. 2005 Mar; 10(3): 251-7.

11. Walker AS, Goings GE, Kim Y, Miller RJ, Chenn A, Szele FG. Nestin reporter transgene labels multiple central nervous system precursor cells. Neural plasticity. 2010 Jan 1; 2010.

12. Fröjdman K, Pelliniemi LJ, LendahI U, Virtanen I, Eriksson JE. The intermediate filament protein nestin occurs transiently in differentiating testis of rat and mouse. Differentiation. 1997 May; 61(4): 243-9.

13. Porter $A G$, Jänicke RU. Emerging roles of caspase-3 in apoptosis. Cell death \& differentiation. 1999 Feb;6(2):99104.

14. Kirsch DG, Doseff A, Chau BN, Lim DS, de Souza-Pinto NC, Hansford R, Kastan MB, Lazebnik YA, Hardwick JM. Caspase3-dependent cleavage of $\mathrm{Bcl}-2$ promotes release of cytochrome c. Journal of Biological Chemistry. 1999 Jul 23; 274(30): 21155-61.

15. Vaux DL, Korsmeyer SJ. Cell death in development. Cell. 1999 Jan 22;96(2):245-54.

16. Kidd VJ. Proteolytic activities that mediate apoptosis. Annual review of physiology. 1998 Mar; 60(1): 533-73.

17. Salvesen GS, Dixit VM. Caspases: intracellular signaling by proteolysis. Cell. 1997 Nov 14; 91(4): 443-6.

18. Weil CS. Tables for convenient calculation of medianeffective dose (LD 50 or ED 50) and instructions in their use. Biometrics. 1952 Sep 1; 8(3): 249-63.

19. Schalm OW. Veterinary Hematology. 4th Edition, Lea and Febiger, Philadelphia, 1986; 8-21.

20. Banni M, Negri A, Dagnino A, Jebali J, Ameur S, Boussetta H. Acute effects of benzo [a] pyrene on digestive gland enzymatic biomarkers and DNA damage on mussel Mytilus galloprovincialis. Ecotoxicology and Environmental Safety. 2010 Jul 1; 73(5): 842-8.

21. Sui L, Li BM. Effects of perinatal hypothyroidism on regulation of reelin and brain-derived neurotrophic factor gene expression in rat hippocampus: role of DNA methylation and histone acetylation. Steroids. 2010 Dec 1; 75(12): 988-97.

22. Kaneko H, Head LM, Ling J, Tang X, Liu Y, Hardin PE, Emery $P$, Hamada FN. Circadian rhythm of temperature preference and its neural control in Drosophila. Current Biology. 2012 Oct 9; 22(19): 1851-7.

23. Shi $Y$, Klutstein $M$, Simon I, Mitchell T, Bar-Joseph Z. A combined expression-interaction model for inferring the 
temporal activity of transcription factors. Journal of Computational Biology. 2009 Aug 1; 16(8): 1035-49.

24. Yuan GC, Ma P, Zhong W, Liu JS. Statistical assessment of the global regulatory role of histone acetylation in Saccharomyces cerevisiae. Genome biology. 2006 Aug; 7(8): 1-9.

25. Singh NP, McCoy MT, Tice RR, Schneider EL. A simple technique for quantitation of low levels of DNA damage in individual cells. Experimental cell research. 1988 Mar 1; 175(1): 184-91.

26. Hajje $G$, Saliba $Y$, Itani $T$, Moubarak $M$, Aftimos $G$, Farès N. Hypothyroidism and its rapid correction alter cardiac remodeling. PloS one. 2014 Oct 15; 9(10): e109753.

27. Kota SK, Meher LK, Kota SK, Jammula S, Modi KD. Carbimazole-induced cholestatic hepatitis in Graves' disease. Indian journal of Endocrinology and metabolism. 2013 Mar; 17(2): 326.

28. Robson NJ. Emergency surgery complicated by thyrotoxicosis and thyrotoxic periodic paralysis. Anaesthesia. 1985 Jan; 40(1): 27-31.

29. Guesnet $P$, Alessandri JM. Docosahexaenoic acid (DHA) and the developing central nervous system (CNS)-implications for dietary recommendations. Biochimie. 2011 Jan 1; 93(1): 7-12.

30. Isaacs EB, Fischl BR, Quinn BT, Chong WK, Gadian DG, Lucas A. Impact of breast milk on intelligence quotient, brain size, and white matter development. Pediatric research. 2010 Apr; 67(4): 357-62.

31. Kafouri S, Kramer M, Leonard G, Perron M, Pike B, Richer L, Toro R, Veillette S, Pausova Z, Paus T. Breastfeeding and brain structure in adolescence. International journal of epidemiology. 2013 Feb 1; 42(1): 150-9

32. Johansen $\mathrm{K}$, Andersen AN, Kampmann JP, Hansen JM, Mortensen HB. Excretion of methimazole in human milk. European journal of clinical pharmacology. 1982 Jul; 23(4): 339-41.

33. Cooper DS, Bode HH, Nath B, Saxe V, Maloof F, Ridgway EC. Methimazole pharmacology in man: studies using a newly developed radioimmunoassay for methimazole. The Journal of Clinical Endocrinology \& Metabolism. 1984 Mar 1; 58(3): 473-9.

34. BRUCKER-DAVIS FR. Effects of environmental synthetic chemicals on thyroid function. Thyroid. 1998 Sep; 8(9): 82756.

35. Nussey S, Whitehead S. The pituitary gland. In Endocrinology: An Integrated Approach 2001. BIOS Scientific Publishers.

36. Calvo R, Obregón MJ, De Ona CR, Del Rey FE, De Escobar GM. Congenital hypothyroidism, as studied in rats. Crucial role of maternal thyroxine but not of 3, 5, 3'-triiodothyronine in the protection of the fetal brain. The Journal of clinical investigation. 1990 Sep 1; 86(3): 889-99.

37. Lavado-Autric R, Ausó E, García-Velasco JV, del Carmen Arufe M, del Rey FE, Berbel P, de Escobar GM. Early maternal hypothyroxinemia alters histogenesis and cerebral cortex cytoarchitecture of the progeny. The Journal of clinical investigation. 2003 Apr 1; 111(7): 1073-82.

38. Ausó E, Lavado-Autric R, Cuevas E, Del Rey FE, Morreale de Escobar G, Berbel P. A moderate and transient deficiency of maternal thyroid function at the beginning of fetal neocorticogenesis alters neuronal migration. Endocrinology. 2004 Sep 1; 145(9): 4037-47.

39. Durkin PR, Emamectin Benzoate. Human Health and Ecological Risk Assessment. Final Report, 2010, Paul Mistretta, COR. USDA/Forest Service, Southern Region. Atlanta, Georgia.

40. Morte $B$, Díez $D$, Auso $E$, Belinchon MM, Gil-lbáñez $P$, Grijota-Martínez C, Navarro D, Morreale de Escobar G, Berbel $P$, Bernal J. Thyroid hormone regulation of gene expression in the developing rat fetal cerebral cortex: prominent role of the $\mathrm{Ca} 2+/$ calmodulin-dependent protein kinase IV pathway. Endocrinology. 2010 Feb 1; 151(2): 81020.

41. Chatonnet F, Flamant F, Morte B. A temporary compendium of thyroid hormone target genes in brain. Biochimica et Biophysica Acta (BBA)-Gene Regulatory Mechanisms. 2015 Feb 1; 1849(2): 122-9.

42. Gil-Ibáñez P, Bernal J, Morte B. Thyroid hormone regulation of gene expression in primary cerebrocortical cells: role of thyroid hormone receptor subtypes and interactions with retinoic acid and glucocorticoids. PloS one. 2014 Mar 11; 9(3): e91692.

43. Gil-Ibañez P, García-García F, Dopazo J, Bernal J, Morte B. Global transcriptome analysis of primary cerebrocortical cells: identification of genes regulated by triiodothyronine in specific cell types. Cerebral cortex. 2017 Jan 1; 27(1): 70617.

44. Marin-Padilla M. Dual origin of the mammalian neocortex and evolution of the cortical plate. Anatomy and embryology. 1978 Jan 1; 152(2): 109-26.

45. Berbel P, Auso E, García-Velasco JV, Molina ML, Camacho M. Role of thyroid hormones in the maturation and organisation of rat barrel cortex. Neuroscience. 2001 Nov 23; 107(3): 383-94.

46. Morreale de Escobar G, Escobar del Rey F, Ruiz-Marcos A. Thyroid hormone and the developing brain," in Congenital Hypothyroidism eds Dussalt JH, Walker P, editors. (New York, NY: Marcel Dekker). 1983; 85-125.

47. Barradas PC, Vieira RS, De Freitas MS. Selective effect of hypothyroidism on expression of myelin markers during development. Journal of neuroscience research. 2001 Oct 15; 66(2): 254-61.

48. Sharlin DS, Tighe D, Gilbert ME, Zoeller RT. The balance between oligodendrocyte and astrocyte production in major white matter tracts is linearly related to serum total thyroxine. Endocrinology. 2008 May 1; 149(5): 2527-36.

49. Alvarez-Dolado $M$, Ruiz $M$, Del Río JA, Alcántara $S$, Burgaya F, Sheldon M, Nakajima K, Bernal J, Howell BW, Curran T, Soriano E. Thyroid Hormone Regulates reelin and dab1Expression During Brain Development. Journal of Neuroscience. 1999 Aug 15; 19(16): 6979-93.

50. Sui L, Ren WW, Li BM. Administration of thyroid hormone increases reelin and brain-derived neurotrophic factor expression in rat hippocampus in vivo. Brain research. 2010 Feb 8; 1313: 9-24.

51. Miyata $T$, Ono $Y$, Okamoto $M$, Masaoka $M$, Sakakibara $A$, Kawaguchi $A$, Hashimoto $M$, Ogawa M. Migration, early axonogenesis, and Reelin-dependent layer-forming behavior of early/posterior-born Purkinje cells in the developing mouse lateral cerebellum. Neural development. 2010 Dec; 5(1): 1-22. 
52. Sui L, Li BM. Effects of perinatal hypothyroidism on regulation of reelin and brain-derived neurotrophic factor gene expression in rat hippocampus: role of DNA methylation and histone acetylation. Steroids. 2010 Dec 1; 75(12): 988-97.

53. Bunker SK, Dandapat J, Sahoo SK, Roy A, Chainy GB. Neonatal Persistent Exposure to 6-Propyl-2-thiouracil, a Thyroid-Disrupting Chemical, Differentially Modulates Expression of Hepatic Catalase and C/EBP- $\beta$ in Adult Rats. Journal of biochemical and molecular toxicology. 2016 Feb; 30(2): 80-90.

54. Bunker SK, Dandapat J, Chainy GB, Sahoo SK, Nayak PK. Neonatal exposure to 6-n-Propyl-Thiouracil, an anti-thyroid drug, alters expression of hepatic DNA methyltransferases, methyl CpG-binding proteins, Gadd45a, p53, and PCNA in adult male rats. European thyroid journal. 2017; 6(6): 28191.

55. Ahmed RG. Perinatal hypothyroidism and cytoskeleton dysfunction. Endocrinol Metab Syndr. 2017; 6(271): 21611017.

56. Michalczyk K, Ziman M. Nestin structure and predicted function in cellular cytoskeletal organisation. Histology and histopathology. 2005.

57. Farwell AP, Dubord-Tomasetti SA, Pietrzykowski AZ, Stachelek SJ, Leonard JL. Regulation of cerebellar neuronal migration and neurite outgrowth by thyroxine and 3, 3', 5'triiodothyronine. Developmental brain research. 2005 Jan 1; 154(1): 121-35.

58. El-Helou V, Dupuis J, Proulx C, Drapeau J, Clement R, Gosselin H, Villeneuve L, Manganas L, Calderone A. Resident nestin+ neural-like cells and fibers are detected in normal and damaged rat myocardium. Hypertension. 2005 Nov 1; 46(5): 1219-25.

59. Manzano J, Bernal J, Morte B. Influence of thyroid hormones on maturation of rat cerebellar astrocytes. International Journal of Developmental Neuroscience. 2007 May 1; 25(3): 171-9.

60. Dahlstrand J, Collins VP, Lendahl U. Expression of the class VI intermediate filament nestin in human central nervous system tumors. Cancer research. 1992 Oct 1; 52(19): 533441.

61. Yang XH, Wu QL, Yu XB, Xu CX, Ma BF, Zhang XM, Li SN, Lahn $B T$, Xiang $A$. Nestin expression in different tumours and its relevance to malignant grade. Journal of clinical pathology. 2008 Apr 1; 61(4): 467-73.

62. Krishnasamy S, Weng YC, Thammisetty SS, Phaneuf D, Lalancette-Hebert $M$, Kriz J. Molecular imaging of nestin in neuroinflammatory conditions reveals marked signal induction in activated microglia. Journal of neuroinflammation. 2017 Dec; 14(1): 1-4.

63. Cao-Sy L, Obara N, Sakamoto T, Kato T, Nishikii H, SakataYanagimoto $\mathrm{M}$, Chiba $\mathrm{S}$. Abnormal Increase in a Distinct
Subset of Nestin-Expressing Cells in the Bone Marrow of Myelodysplastic Syndromes. Blood. 2016; 3887.

64. Elmore S. Apoptosis: a review of programmed cell death. Toxicologic pathology. 2007 Jun; 35(4): 495-516.

65. Guanggang $X$, Diqiu $L$, Jianzhong $Y$, Jingmin $G$, Huifeng $Z$, Mingan S, Liming T. Carbamate insecticide methomyl confers cytotoxicity through DNA damage induction. Food and Chemical toxicology. 2013 Mar 1; 53: 352-8.

66. Gilles AF, Schinko JB, Averof M. Efficient CRISPR-mediated gene targeting and transgene replacement in the beetle Tribolium castaneum. Development. 2015 Aug 15; 142(16): 2832-9.

67. Singh R, Upadhyay G, Godbole MM. Hypothyroidism alters mitochondrial morphology and induces release of apoptogenic proteins during rat cerebellar development. Journal of Endocrinology. 2003; 176: 321-329.

68. Huang XW, Yang RL, Zhao ZY, Ji C, Yang RW. Mechanism for apoptosis of hippocampus neuron induced by hypothyroidism in perinatal rats. Zhejiang da xue xue bao. Yi xue ban= Journal of Zhejiang University. Medical sciences. 2005 Jul 1; 34(4): 298-303.

69. Sinha RA, Pathak A, Kumar A, Tiwari M, Shrivastava A, Godbole MM. Enhanced neuronal loss under perinatal hypothyroidism involves impaired neurotrophic signaling and increased proteolysis of p75NTR. Molecular and Cellular Neuroscience. 2009 Mar 1; 40(3): 354-64.

70. Li D, Huang $Q$, Lu M, Zhang L, Yang Z, Zong M, Tao L. The organophosphate insecticide chlorpyrifos confers its genotoxic effects by inducing DNA damage and cell apoptosis. Chemosphere. 2015 Sep 1; 135: 387-93.

71. Cohen GM, Sun XM, Snowden RT, Dinsdale D, Skilleter DN. Key morphological features of apoptosis may occur in the absence of internucleosomal DNA fragmentation. Biochemical Journal. 1992 Sep 1; 286(2): 331-4.

72. Kassie F, Parzefall W, Knasmüller S. Single cell gel electrophoresis assay: a new technique for human biomonitoring studies. Mutation Research/Reviews in Mutation Research. 2000 Jun 1; 463(1): 13-31.

73. McArt DG, McKerr G, Howard CV, Saetzler K, Wasson GR. Modelling the comet assay. Biochemical Society Transactions. 2009 Aug 1; 37(4): 914-7.

74. Celik-Ozenci C, Tasatargil A, Tekcan M, Sati L, Gungor E, Isbir $M$, Usta MF, Akar ME, Erler F. Effect of abamectin exposure on semen parameters indicative of reduced sperm maturity: a study on farmworkers in A ntalya (T urkey). Andrologia. 2012 Dec; 44(6): 388-95.

75. Azoz A, Ibrahim KA, Kader IY, Tawfik AR. Tracking of Apoptosis Induced by Emamectin Benzoate in Fetuses of Hypothyroid Rats. Int. J. Pharm. Sci. Rev. Res., 2020; 63(1): 81-89.

Source of Support: None declared.

Conflict of Interest: None declared.

For any question relates to this article, please reach us at: editor@globalresearchonline.net

New manuscripts for publication can be submitted at: submit@globalresearchonline.net and submit_ijpsrr@rediffmail.com 